\title{
Hivatkozási mintázatok, izoláció és ülésvezetôi kontroll az 1924. évi középiskolai törvény nemzetgyülési vitájában
}

A politikai atmoszféra jellemzôinek egybevetése ösztönzóleg hat annak vizsgálatára, hogy a sajátos felütéssel meginduló vitában milyen eróhatások érik, formálják a törvényjavaslathoz kapcsolódó felszólalások, megnyilvánulások struktúráját. ${ }^{1}$ A tanulmány célja annak kideritése, hogy ez a hálózat (és a hozzá kapcsolódó egyéb attribútumok) egybeesnek-e azokkal a fentebb leirt törésvonalakkal, amelyek a Trianon utáni Magyarország parlamentáris kultúráját (ezen belül is oktatásügyi törvényhozását) jellemezték.

\section{Bevezetés}

A két világháború közötti időszak - összevetve a dualizmus, valamint a második világháború utáni négy és fél évtized periódusával - az 1867 és 1990 közötti magyar oktatásügyi törvényalkotás (időarányosan) legintenzívebb szakasza. A gyors ütemü jogalkotás gyakorlatilag kényszert jelentett a parlament számára, hiszen a trianoni békeszerződés, valamint a forradalmak következményeként a társadalomban számottevően nőtt a jogbiztonság igénye; a törvényhozás terén pedig a magyar társadalom modernizációjához elsősorban az oktatáspolitika járult hozzá (Kulcsár, 1996).

Ezen oktatásügyi törvények sorát gyarapította a 1924. évi középiskolai törvény is, amely egy újabb intézménytípus, a reálgimnázium bevezetésével háromosztatú fiúközépiskola-rendszert hozott létre. A törvény ezzel egyértelmü állásfoglalást tett az egységesség és a differenciálás hosszú évtizedekre visszanyúló vitájában. Elődjéhez, az 1883. évi középiskolai törvényhez hasonlóan azonban ez a döntés sem volt mentes a szakmai és politikai vitáktól. Ennek ellenére a vonatkozó szakirodalomban mindössze három olyan tételt (Nagy, 2000; Simon, 1959; Szabó, 2000) leltem fel, aminek célja kifejezetten a jogszabály és annak kontextusának elemzése volt. Ezekben megemlítik vagy idézik a parlamenti vita során elhangzott felszólalásokat is, de a tíz naptári napot felölelő diskurzus átfogó elemzésére eddig még nem történt vállalkozás. ${ }^{2}$

Boros és Szabó $(2008,333$. o.) az ugyanebben az időszakban megszülető népiskolai törvény kapcsán jegyzi meg, hogy bár mind a kormányoldal, mind az ellenzék a politikai szempontok kizárását hangsúlyozta, a vita mégis a „szokásos (a konszolidációs bethleni időszakra jellemzően) nemzeti-konzervatív és liberális-szociáldemokrata érvek melletti megoszlást mutatta". Ebben nem elhanyagolható szempontot jelentett, hogy 
az oktatásügyi törvények a Horthy-korszak jogalkotásának szenzitív terepét, ideológiai vonatkozásaik megkerülhetetlensége miatt pedig szinte minden alkalommal ütközési pontját is jelentették. Ellenzéki oldalról ennek meghatározó hányadát a legtöbb mandátumot birtokló párt, a szociáldemokraták aktivitása adta, akik számára a legnagyobb kritikai mozgásteret a nemzetgyülés fóruma nyújtotta (Varsányi, 2013). Az ellenzéki véleményeket a kormánypárt előzetes egyeztetésekkel, esetenként kompromisszumokkal, illetve az össznemzeti érdek gondolatköréhez (vö. pl. Drabancz, 2000; T. Kiss, 1998) tartozó érvekkel tudta ellensúlyozni. A középiskolai törvényjavaslat nemzetgyülési vitájában Klebelsberg miniszteri expozéjának már egyik első mondata is a pártérdekektől való függetlenséget hangsúlyozta: „Az a javaslat, amelyet mostan tárgyalunk, apolitikus javaslat a szó legszorosabb értelmében. Apolitikus javaslat olyan értelemben, hogy egy szemernyi sincs benne abból a mixtum compositumból, amiról mi magyarok valahogy azt képzeljük, hogy politika s amiből valamit mindig belekeverünk az anyagba, amelytől az elgennyesedik. Én remélem, hogy azonképen, amint a bizottság, mondhatom, példáját adta annak, hogyan kell egy nehéz kérdést tisztán szakszempontból kezelni, a plénum is ezt az apolitikus javaslatot tisztán pedagógiai szempontból nézi, a magyar ifjúság $\mathrm{s}$ a magyar nemzet nagy érdekei szempontjából mérlegeli." (NN, 1922, 3. o.) Klebelsberg esetében a (közép)iskola-ügy apolitikus jellegének kiemelése nem egyszeri jelenség, hiszen a nemzetgyülés 1923. évi augusztus 31-iki ülésén, A kultusztárca és a tisztviselői létszámcsökkentés témájában tartott beszédében, valamint az 1924. január 29-én tartott felszólalásában is (Közoktatásügyi és kulturális feladatok) is utal rá (Klebelsberg, 1927). ${ }^{3}$

A politikai atmoszféra jellemzőinek egybevetése ösztönzőleg hat annak vizsgálatára, hogy a sajátos felütéssel meginduló vitában milyen eröhatások érik, formálják a törvényjavaslathoz kapcsolódó felszólalások, megnyilvánulások struktúráját. A tanulmány célja annak kiderítése, hogy ez a hálózat (és a hozzá kapcsolódó egyéb attribútumok) egybeesnek-e azokkal a fentebb leírt törésvonalakkal, amelyek a Trianon utáni Magyarország parlamentáris kultúráját (ezen belül is oktatásügyi törvényhozását) jellemezték.

\section{Problémafelvetés és hipotézisek}

A tanulmány központi problémafelvetése szerint a törvényjavaslat támogatóinak és ellenzőinek viszonya a diskurzus dinamikai jellemzőiben is érvényesül. Ez a hatás két faktorból adódik össze: az egyik az ülésvezető kontrolláló tevékenysége, amely esetében azt is feltételezem, hogy a vita után bő fél évvel megszülető házszabály-módosítás korlátozó szándékai már ekkor tetten érhetőek. A másik összetevőt a képviselők (és a miniszter) diskurzusát leképező erőtér, illetve az abban fellelhető hivatkozási preferenciák és izolációs technikák adják.

A hipotézisek első csoportja tehát a felszólalások korlátozására irányul, melynek két típusa különböztethető meg: a tartalmi, illetve az időbeli limitálás. Míg előbbi megítélése meglehetősen szubjektív szempontok mentén történhet, utóbbira az 1924-es házszabálymódosításig elvben nem volt lehetőség (kivéve, ha az adott hozzászólás már túllépte a teljes témára szánt időkeretet). Az elaprózottság elkerülése végett a korlátozások ezen két típusa együttesen kerül statisztikai elemzésre, a minőségi különbségeket pedig szövegesen jelzem.

1: A nemzetgyülési vita során házelnök és az alelnökök nagyobb arányban korlátozzák a javaslatot ellenzők hozzászólásait, mint a támogató hozzászólásokét.

1/a: Az általános vita során házelnök és az alelnökök nagyobb arányban korlátozzák a javaslatot ellenzők hozzászólásait, mint a támogató hozzászólásokét.

1/b: A részletes vita során házelnök és az alelnökök nagyobb arányban korlátozzák a javaslatot ellenzők hozzászólásait, mint a támogató hozzászólásokét. 
A hipotézisek második csoportja a képviselők és a miniszter vélt hivatkozási preferenciáin alapul. A 2. hipotézis alapját az az elképzelés adja, miszerint a támogató/ellenző hivatkozások arányában eltérés mutatkozik két attitüdű csoport között. A 3. hipotézis ezzel szemben annak vizsgálatára irányul, hogy a hivatkozó hozzászólás attitüdjével azonos/ellentétes hozzászólások megemlítésében milyen aránybéli különbségek lelhetőek fel a két csoport között.

2: A javaslatot ellenző hozzászólások nagyobb arányban hivatkozzák a korábban elhangzó pozitív attitüdű hozzászólásokat, mint a támogató hozzászólások.

3: A javaslatot ellenző hozzászólások hajlamosabbak a velük ellentétes attitüdű hozzászólások hivatkozására, mint a támogató hozzászólások.

A hipotézisek harmadik csoportja a képviselők és a miniszter vélt izolációs technikáin alapul. E szerint a hozzászólásoknak három csoportja határozható meg: a hivatkozásokat kizárólag kezdeményező (forrás), kizárólag fogadó (nyelö), illetve a hivatkozási rendszerből kiszoruló (alulról és felülről is izolált csúcs). ${ }^{4}$ A hipotézisek az ellenzék aktívabb részvételét, egyúttal azt is feltételezi, hogy a hivatkozást nem kezdeményező negatív attitűdű megnyilvánulások kiszorulnak a diskurzusból.

4/a: A javaslatot ellenzők körében nagyobb arányban lelhetőek fel a hivatkozásokat kizárólag kezdeményező hozzászólások, mint a támogatók között.

4/b: A javaslatot támogatók körében nagyobb arányban lelhetőek fel a hivatkozásokat kizárólag fogadó hozzászólások, mint az ellenzők között.

4/c: A javaslatot ellenzők között nagyobb mértékben lelhetőek fel a teljesen izolált hozzászólások, mint a támogatók körében.

\section{Források}

A kutatás egyik forrását az Országgyülési dokumentumok címet viselő online adatbázis jelentette. Az itt található digitalizált iratanyagok közül az 1922. június hó 16-ára hirdetett Nemzetgyülés Naplójának XXII. kötetét használtam fel (NN, 1922). További kiegészítő forrásokat jelentett Baján (1922) parlamenti almanachja, valamint Klebelsberg (1927) beszédeinek és cikkeinek gyüjteménye.

\section{Módszerek}

A kutatás során rögzített változókat és értékeiket egy adatbázis tömöríti, amely kettős célt szolgál: egyrészről ennek segítségével rajzolhatóak fel a később elemzett hivatkozási mintázatok (ezeket gráfok reprezentálják), másrészről a kiegészítő statisztikai számítások alapját is ez az adattábla szolgáltatja. A vita gráfelméleti megközelítését Sanda (2008) és Varga (2008) számítógéppel támogatott diskurzus- és tartalomelemzést bemutató tanulmányai ihlették, e felvetések alapján kezdtem meg a gráfelméleti megközelítés jelen vitára való adaptációjának kidolgozását. ${ }^{5} \mathrm{~A}$ tanulmányokban alapul vett irányított körmentes gráfok ${ }^{6}$ segítségével ugyanis a parlamenti viták is modellezhetővé válnak: a hozzászólás-alapú gráfok csúcsait az egyes megnyilvánulások, irányított éleit pedig az egyes reflexiók (hivatkozások) képezik.

Mind a gráfok felépítéséhez, mind az elemzéshez a yEd diagramszerkesztő szoftver 3.10.1-es verzióját használtam fel. Az elemzés során az egyes hozzászólások (sorszámukat \#-tel jelöltem) hálózatban betöltött helyzete volt az egyik kulcskérdés. Irányított gráfok esetében a befok (az adott csúcsba beérkező élek száma, vagyis a hivatkozottság mértéke), illetve a kifok (csúcsból kiinduló élek száma, vagyis a hivatkozások mértéke) alapján 
is súlyozhatjuk a hálózatot. Az így kapott ábrákon mind a meghatározó (domináns) hozzászólások, mind a valamilyen szempontból (alulról, felülről vagy minkét irányból) izolált csúcsok is beszédesek lehetnek. Az elemzést kiegészítő statisztikai próbákhoz a Microsoft Excel és az SPSS szoftvereket használtam fel.

\section{Eredmények $^{7}$}

\section{$A$ vita általános jellemzői és fontosabb számadatai}

A március 26-án 11:40-kor kezdődő első vitanapot a korona értékcsökkenésének gátlását célzó törvény harmadszori felolvasása nyitotta. A törvény elfogadását az egyes bizottságokban megüresedő helyekre történő választás, majd a középiskolai törvényjavaslat vitája követte. A tervezetet Vasadi-Balogh György, a Közoktatásügyi bizottság tagja prezentálta, később Klebelsberg Kunó expozéjának keretében kapott részletesebb indoklást. A miniszteri felszólalást az általános vita követte, melyben a javaslatot támogató és ellenző megnyilvánulások egyaránt helyet kaptak. Az általános vita lezárultát követően április 3-án került sor a részletes vitára, másnap a törvényjavaslat szövegének harmadszori felolvasásával fejeződött be a középiskolai törvényjavaslat nemzetgyülési tárgyalása.

A teljes vita tehát 10 naptári napot (1924. március 26.-1924. április 4.) ölelt fel. A vasárnapi szünettel rendelkezésre álló 9 vitanapból 8 napon tárgyalták a középiskolai reformjavaslatot, így utóbbi szám tekinthető releváns vitanapnak. ${ }^{8}$ Típusát tekintve a vitanapok döntő hányadában az általános vita folyt, amely még a 9. napon is zajlott. A 111. hozzászólással (9. nap) történt meg az általánosságban elfogadás megállapítása, ezt a határozati javaslatok követték egészen a 136. hozzászólásig (9. nap).

A(vita)napok heterogén halmazt alkotnak mind az elhangzott legitim megnyilvánulások számát, mind azok terjedelmét tekintve. Míg az első két napon mindössze 7 , illetve 8 megnyilvánulásra nyílik lehetőség, addig az egymást követő 3., 6., 7. és 8. vitanapok rendre kétszámjegyü hozzászólásszámot produkáltak. A csúcspontot a 9. nap jelenti, a maga 129 legitim megnyilvánulásával, míg az alsó határ a 10. nap mindössze 3 hozzászólása.

A megnyilvánulások kumulatív terjedelme azonban nem követi szorosan hozzászólások számát, ami több oknak is betudható: a vitanapok vegyesek abból a szempontból, hogy hány semleges attitüdü (azaz az ülés levezetéséhez, adminisztrációjához stb. tartozó, az elnöktől, a jegyzőkönyvvezetőtől vagy jegyzőktől származó) hozzászólás hangzik el, amelyek átlagban jóval rövidebbek a pozitív és negatív attitüdü - azaz érdemi - hozzászólásoknál. ${ }^{9}$ A másik ok a vita típusában keresendő: az általános vita hozzászólásainak átlagos hossza jóval nagyobb, mint a részletes vita megnyilvánulásaié, ennek köszönhető, hogy a 9. nap a maga 129 hozzászólásával csak a 4. pozíciót foglalja el a terjedelem tekintetében. ${ }^{10}$ Mivel a heterogenitás ellenére a terjedelem relatíve szük tartományon belül mozog (82 423-131 790 n, leszámítva az egyértelmüen kivételt képező 10. nap esetében), és intuitív módon feltételezhető, hogy az egyes vitanapokon nagyságrendileg hasonló energiát fordítottak egy-egy témára, így levonható a következetés, hogy ez a változó a hozzászólások időbeni terjedelmét is jól mérheti. A teljes vita során 34 személy nyilvánult meg legitim módon, akik 237 hozzászólást produkáltak, 770 $604 \mathrm{n}$ terjedelemben.

E hozzászólások között a vita során összesen 460 hivatkozás regisztrálható. Ezek közül azonban nem mindegyik irányul ténylegesen egy adott hozzászólásra. A referenciákat az adott megnyilvánulással való kapcsolata szerint három csoportra bonthatjuk: az első csoportot az ún. tényleges referenciák alkotják, melyek valóban a vita egy adott pontjára utalnak. A második csoportot az ,álhivatkozások” képezik (amelyek egyértelmüen nem a vita egy adott megnyilvánulására, hanem egy korábbi írásos vagy szóbeli aktusra, vagy 
egy-egy, a vitában is résztvevő személyre vonatkoznak), ezeket a pseudo- címkével illetem. A harmadik, közbenső csoport azokat a hivatkozásokat fogja egybe, amelyek esetében nem egyértelmü, hogy egy adott hozzászóló egy adott javaslat írott vagy szóbeli változatára hivatkozott-e. E csoport megnevezése felemás jellegének megfelelően semi-. Ezt a három halmazt egészíti ki azon hivatkozások „,?”-lel jelölt csoportja, melyek célhozzászólása nem beazonosítható (elhanyagolható kisebbség), vagy egyszerre több képviselöt érint (döntő többség). A négy csoport arányait az 1. táblázat szemlélteti.

1. táblázat. A vita során rögzitett hivatkozások típus szerinti megoszlása

\begin{tabular}{|l|c|c|c|c|c|}
\hline & Tényleges & Semi- & Pseudo- & $?$ & Összesen \\
\hline Darab & 193 & 49 & 152 & 66 & 460 \\
\hline$\%$ & $42 \%$ & $11 \%$ & $33 \%$ & $14 \%$ & $100 \%$ \\
\hline
\end{tabular}

Mint látható, az összes hivatkozás jelentős többségét, 42 százalékát a tényleges hivatkozások alkotják. Az elsősorban több képviselőre történő hivatkozásokat tömörítő „?”-es csoport hozzáadásával az arány 56 százalékra nő. Ezzel szemben a referenciák közel egyharmadát (33 százalék) pseudo-hivatkozások, 11 százalékát semi-hivatkozások alkotják. Mindez azt mutatja, hogy a hivatkozások egy meghatározó hányada (minimum egyharmada, de akár közel fele is) nem a diskurzusra, hanem azon kívülre irányul.

A nemzetgyülésben zajló vita főbb paramétereit a 2. táblázat foglalja össze.

2. táblázat. A középiskolai törvényjavaslat nemzetgyülési vitájának föbb paraméterei

\begin{tabular}{|c|c|c|c|c|c|c|c|c|c|c|}
\hline Nap száma & 1. & 2. & 3. & 4. & 5. & 6. & 7. & 8. & 9. & 10. \\
\hline $\begin{array}{l}\text { Ülésnap } \\
\text { száma }\end{array}$ & 261. & 262. & 263. & 264. & - & 265. & 266. & 267. & 268. & 269. \\
\hline Dátum & 03.26 & 03.27 & 03.28 & 03.29 & 03.30 & 03.31 & 04.01 & 04.02 & 04.03 & 04.04 \\
\hline Nap & szerda & $\begin{array}{l}\text { csütör- } \\
\text { tök }\end{array}$ & péntek & $\begin{array}{l}\text { szom- } \\
\text { bat }\end{array}$ & $\begin{array}{l}\text { vasár- } \\
\text { nap }\end{array}$ & hétfő & kedd & szerda & $\begin{array}{l}\text { csütör- } \\
\text { tök }\end{array}$ & $\begin{array}{l}\text { pén- } \\
\text { tek }\end{array}$ \\
\hline $\begin{array}{l}\text { Ülésnap-e? } \\
\text { (igen /I/, } \\
\text { nem /N/) }\end{array}$ & I & I & I & I & - & I & I & I & I & I \\
\hline $\begin{array}{l}\text { Középiskola } \\
\text { téma-e? (igen } \\
\text { /I/, nem /N/) }\end{array}$ & I & I & I & $\mathrm{N}$ & - & I & I & I & I & I \\
\hline $\begin{array}{l}\text { Vita típusa: } \\
\text { általános }(\AA), \\
\text { részletes }(\mathrm{R}), \\
\text { harmadszori } \\
\text { felolvasás }(3)\end{array}$ & Á & Á & Á & - & - & Á & Á & Á & Á/R & 3 \\
\hline $\begin{array}{l}\text { Legitim } \\
\text { megnyilvánu- } \\
\text { lások száma } \\
\text { (db) }\end{array}$ & 7 & 8 & 29 & - & - & 22 & 22 & 16 & 129 & 3 \\
\hline $\begin{array}{l}\text { Téma terje- } \\
\text { delme (n) }\end{array}$ & 102542 & 82423 & 131790 & - & - & 123624 & 126179 & 100474 & 103109 & 419 \\
\hline $\begin{array}{l}\text { Hivatkozások } \\
\text { száma }(\mathrm{db})\end{array}$ & \multicolumn{10}{|c|}{460} \\
\hline
\end{tabular}




\section{Attitüdtérkép}

A táblázatban összegzett legitim megnyilvánulások minősége (törvényjavaslattal szembeni attitüdje) háromféle lehet: semleges, támogató vagy ellenző. Ezek azért állapíthatóak meg ilyen kategorikusan, mert a megnyilvánulók felszólalásuk végén egyértelmüen nyilatkoztak arról, hogy elfogadják-e a törvényjavaslatot, vagy sem. A semleges attitüdü megnyilvánulások csoportja - mint korábban utaltam rá - az ülésvezető, a jegyzőkönyvezető és a jegyzők hozzászólásaiból lett képezve.

Ezen attitűdök, valamint az 1. táblázatban megjelenő adatok (adatbázisbéli eredetijének) kombinációjából egy térkép képezhető, ami lehetővé teszi a két halmaz kölcsönhatásának vizsgálatát. Az 1. ábra a parlamenti vita hozzászólásainak (a törvényjavaslathoz való viszony alapján színezett) térképét, valamint különböző hivatkozások hálózatát mutatja be. Az egyes hozzászólások vitanap szerinti bontásban jelennek meg. A hivatkozásokat irányított élek reprezentálják, a nyilak a hivatkozás irányát, az élek súlyai a hivatkozások összevont számát jelölik. A nem azonosítható (vagy csoportra irányuló) hivatkozásokat a kép jobb oldalán elhelyezkedő, kérdőjeles csoport foglalja magába.

Az ábrán látható hozzászólások átlagos fokszáma (a kérdőjeles csoport nélkül) 0,81 , az általánosságban elfogadás időszakáig (azaz a \#110-es hozzászólással bezárólag) pedig 1,3. Ez a két középérték azonban meglehetősen félrevezető, mivel a semleges attitüdü hozzászólások jellemzően 0 , vagy ehhez közeli értékei rontják a teljes vita fokszámátlagát (ehhez képest viszont a vita dinamikájára alacsony hatással bírnak).

\section{Érdemi hozzászólások}

A neutrális attitüdủ hozzászólások elemzése tehát kevés többlet-információval jár, azonban jelentősen torzítják mind a gráfok, mind a statisztikák arányait. Ezért a további analízishez már csak az érdemi - azaz a semlegesen viszonyulók nélküli - hozzászólásokat használtam fel. Amint a 2. ábrán látható, az ezek kiemelésével képzett attitűdtérkép hozzászólásainak mintázata jelentősen megritkul.

\section{Hivatkozottsági mintázatok}

A 3. ábra a vita egyes hozzászólásainak hivatkozottsága (adott csúcsainak befoka) alapján súlyozott hálózatát mutatja. A színezést és a befokok (a maximális tapasztalt értékhez mért) arányait jelölő címkéket kizárólag a jobb átláthatóság kedvéért alkalmaztam. A gráf „fejnehézsége” (a korábbi hozzászólások felé való „billenése”) egyszerű oknak köszönhető: a korábban felszólaló személyeknek nyilvánvalóan nagyobb esélyük van arra, hogy többen hivatkozzák öket. De - amint az ábra is mutatja - ez a kronológiai előny nem magyaráz mindent. A hivatkozottságok sajátos mintázatának formálásában más faktorok (mint a presztízs, hozzászólás hossza stb.) is jelentős szerepet játszhattak.

Az ábrán egyértelmüen két csúcs tünik ki: Klebelsberg miniszteri expozéja (\#4), valamint az azonosítatlan, vagy több hozzászólásra hivatkozó \#?-es csoport. Az első két hozzászólást meglehetősen nagy, közel 60 százalékpontnyi visszaeséssel követi Perlaki György felszólalása (\#11). A további helyezések már jóval szétszórtabban helyezkednek el a többi vitanapon, Vasadi-Balogh György (\#2) és Kéthly Anna (\#7) nyitó napon elhangzó beszédei (előbbi egyben a törvényjavaslat prezentálása is volt!) mellett Petrovácz Gyula (\#24) ötödik, illetve Bozsik Pál (\#47) hatodik napi felszólalásainak hivatkozottsága számottevő. Időpontjaik különbözősége ellenére azonban referáltságuk szűk 

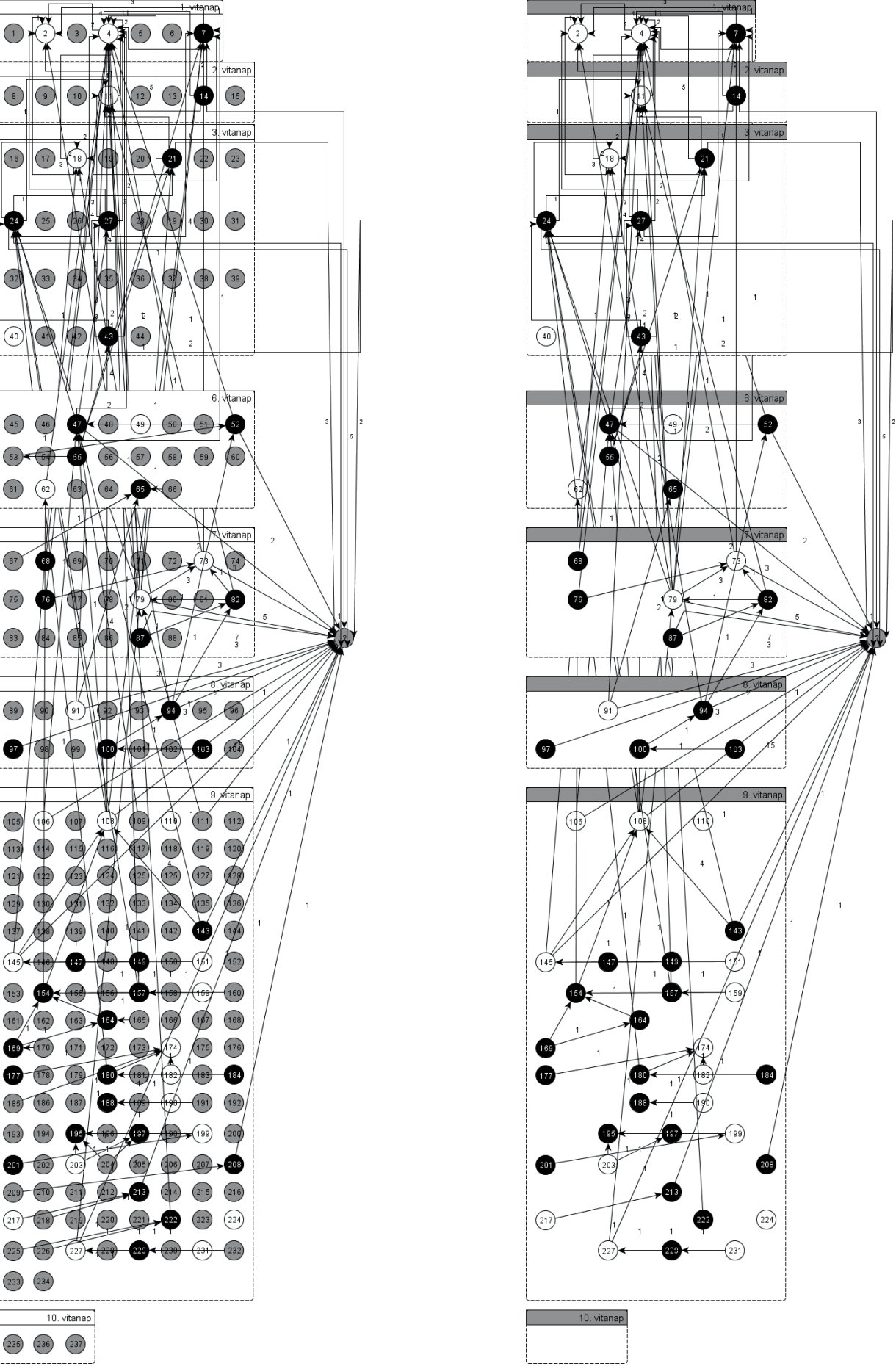

1. ábra. A vita attitüdtérképe 
tartományon belül mozog. Az ezt követő hozzászólások már mind 10 százalék alatti hivatkozottságúak, amiben nem elhanyagolható szerepet játszik az is, hogy a részletes vita kezdetével érzékelhetően visszazuhan a hozzászólások referáltsága (0 és 5 százalék között mozog).

\section{Hivatkozási mintázatok}

Enyhe „farnehézsége” okán a 4. ábra első pillantásra a 3. sz. ábra inverzének tünhet, de ebben az esetben meröben más faktor jelenti a súlyozás alapját. ${ }^{11}$ Bár - a vita korábban már említett linearitásából adódóan - itt nyilván a később elhangzó felszólalások élveznek előnyt, első pillantásra is szembetünő különbség, hogy a befokkal szemben mennyivel „kiegyensúlyozottabb”, kevésbé aszimmetrikus képet mutat a kifok alapján súlyozott hálózat.

A legnagyobb hivatkozási aktivitást mutató hozzászólás Klebelsberg Kunóé (\#108), ami annak fényében, hogy az általános vita során az utolsó előtti hozzászólás volt, már kevésbé meglepő. A hozzászólások következő csoportjának aktivitása már ennek kétharmadát sem éri el - ezt leszámítva azonban kevés közös jellemzőjük akad: Hegymegi-Kiss Pál (\#27), Bozsik Pál (\#47) és Maday Gyula (\#79) hozzászólásai ugyanis a befoglaló vitanapok és az attitüd szempontjából is vegyesek.

Akár a 3., akár a 4. ábra esetében levonható a következtetés, hogy meghatározó pontjaikban nem lelhető fel érdemi, attitüdhöz köthető aránytalanság. A domináns csúcsok mellett azonban hasonlóan izgalmas lehet a hozzászólások a másik véglete, vagyis a hivatkozásokat nem fogadó, nem kezdeményező, vagy mindkét tulajdonságot magukon hordozó csúcsok.

\section{Források, nyelők, izolált csúcsok}

Az érdemi hozzászólások gráfja, valamint ennek súlyozott változatai (2., 3. és 4. ábra) 26

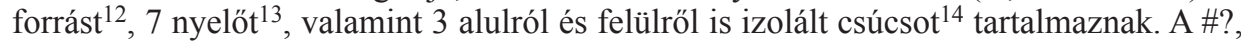
\#2 és \#231 hozzászólásokat nem vettem figyelembe a végleges halmazok kialakításakor, mivel ezeknek nem volt lehetősége érdemi hozzászólásokra hivatkozni, vagy azoktól utalást kapni. Ezzel a kritériummal szükítve 25 forrást, 5 nyelőt és 3 alulról és felülről is izolált csúcsot tartalmaz a gráf, melyek attitüd szerinti megoszlása érdekes mintázatot mutat (3. táblázat).

3. táblázat. A források, a nyelök és az alulról és felülröl is izolált csúcsok aránya a támogatók és az ellenzök körében

\begin{tabular}{|l|c|c|c|}
\hline & Forrás $(I / N)$ & Nyelö $(I / N)$ & Izolált $(I / N)$ \\
\hline Támogató & $10 / 13$ & $1 / 22$ & $2 / 21$ \\
\hline Ellenző & $15 / 21$ & $4 / 32$ & $1 / 35$ \\
\hline
\end{tabular}

Könnyen észlelhető, hogy az oszlopok egy-egy $2 * 2$ kereszttáblát rejtenek. A hipotézisekhez kapcsolódóan mindhárom esetben megvizsgáltam az izoláltság attitüddel való összefüggését.

A forrásokhoz kapcsolódó hipotézis esetében (4/a) a Khí-négyzet próba eredménye $\left(\chi_{\text {megfigyelt }}^{2}=0,01\right) 5$ százalékos szignifikanciaszint $(\alpha=0,05)$ mellett a küszöbérték $\left(\chi_{\text {elméleti }}=3,84\right)$ alatti. Így a nullhipotézis nem vethető el, a táblázat nem mutat szignifikáns összefüggést. A nyelők és az izolált csúcsok esetében két, illetve négy határérték 


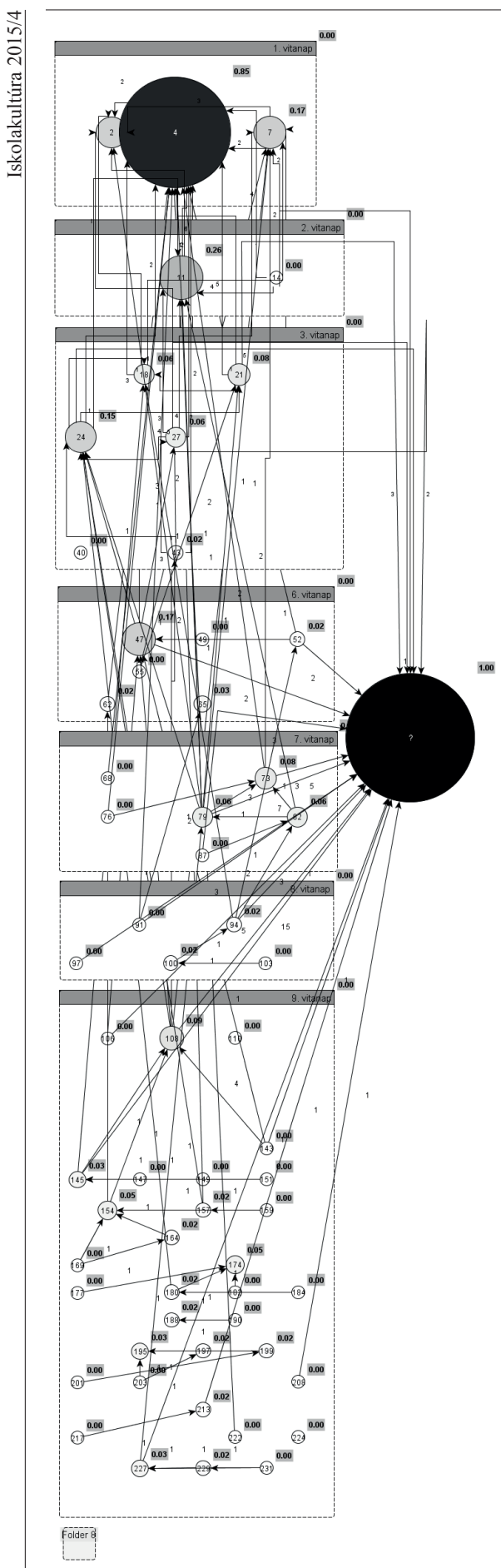

3. ábra. Az érdemi hozzászólások befok alapján súlyozott változata

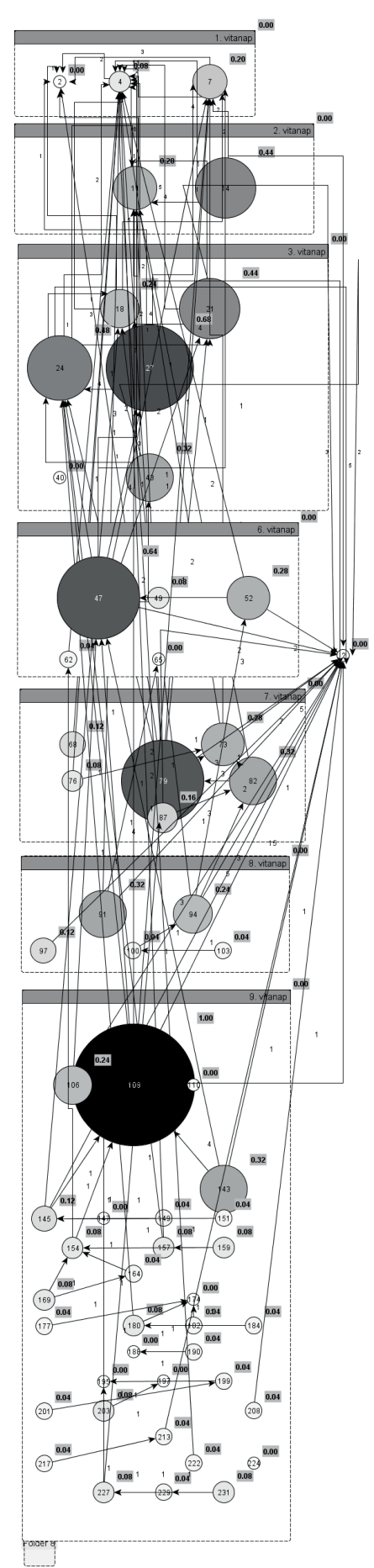

4. ábra. Az érdemi hozzászólások kifok alapján súlyozott változata 
(5) alatti cella is megjelent a kapcsolódó kontingencia-táblázatban, így helyettesítő megoldásként a Fisher-féle egzakt próbát alkalmaztam. A 4/b hipotézis esetében 0,64-es, míg a 4/c hipotézis esetében 0,55-ös P értéket kaptam, így egyik esetben sem vethető el a nullhipotézis.

\section{A hivatkozások megoszlása az attitüd mentén}

Kérdéses, hogy az attitűd mennyiben befolyásolta a hivatkozási mátrixot. Ennek összesített változatát az 4. táblázat szemlélteti.

4. táblázat. A támogatókra és ellenzőkre irányuló hivatkozások attitüd szerinti eloszlása

\begin{tabular}{|l|l|c|c|}
\hline \multicolumn{2}{|c|}{} & \multicolumn{2}{|c|}{ A hivatkozott hozzászólás attitüdje } \\
\cline { 3 - 4 } \multicolumn{2}{|c|}{} & Támogató & Ellenzö \\
\hline \multirow{2}{*}{ A hivatkozás attitűdje } & Támogató & 33 & 27 \\
\cline { 2 - 4 } & Ellenző & 75 & 33 \\
\hline
\end{tabular}

Az 2. hipotézishez kapcsolódó Khí-négyzet próba eredménye $\left(\chi_{\text {megfigyelt }}^{2}=3,51\right) 5$ százalékos szignifikanciaszint $(\alpha=0,05)$ mellett a küszöbérték $\left(\chi_{\text {elméleti }}^{2}=3,84\right)$ alatti. Igy a nullhipotézis nem vethető el, a táblázat nem mutat szignifikáns összefüggést.

A fenti kereszttábla mellett érdemes lehet megvizsgálni a két csoport hivatkozási preferenciáit aszerint is, mennyire hajlamosak a velük azonos, illetve ellentétes attitüdü hozzászólások hivatkozására. Ezen (5.) táblázat értékei a 4. táblázat alsó sorában található számok felcserélésével kaphatóak meg.

5. táblázat. A támogatókra és ellenzökre irányuló hivatkozások attitüd szerinti eloszlása

\begin{tabular}{|l|l|c|c|}
\hline \multicolumn{2}{|c|}{} & \multicolumn{2}{|c|}{ A hivatkozott hozzászólás attitüdje } \\
\cline { 3 - 4 } \multicolumn{2}{|c|}{} & Azonos & Ellentétes \\
\hline \multirow{2}{*}{ A hivatkozás attitűdje } & Támogató & 33 & 27 \\
\cline { 2 - 4 } & Ellenző & 33 & 75 \\
\hline
\end{tabular}

Az 3. hipotézishez kapcsolódó Khí-négyzet próba eredménye $\left(\chi_{\text {megfigyelt }}^{2}=9,66\right) 5$ százalékos szignifikanciaszint $(\alpha=0,05)$ mellett a küszöbérték $\left(\chi_{\text {elméleti }}=3,84\right)$ feletti. Így a nullhipotézis elvethető, a táblázat szignifikáns összefüggést mutat. Az értékeket áttekintve látható a különbség: míg a támogató hozzászólások kiegyenlítetten, pontosabban enyhe aránytalansággal (55 és 45 százalék) hivatkozzák az azonos és az ellentétes attitüdủ megnyilvánulásokat, addig az ellenzők esetében a hozzászólások több mint kétharmada az ellentétes attitüdre irányul (31 és 69 százalék). Azonban a fenti két számítás egyike sem veszi figyelembe a felszólalók számának különbségét (ti. 25 támogató és 36 ellenző hozzászólás hangzott el), ami az enyhe túlsúlyt (vagyis a támogatók részéről az ellenzék hozzászólásainak mellőzését) növeli, az ellenzők esetében pedig még markánsabbá teszi az ellentétes attitüdre való hivatkozás szándékát. 


\section{A hozzászólások korlátozása az ülésvezetö részéröl}

A hozzászóló korlátozása alatt ebben a tanulmányban az értendő, amikor a házelnök illetve a két alelnök - (akár tartalmi, akár időbeli vonatkozásban) korlátozni vagy módosítani kívánja az adott felszólalást. A teljes vita során 8 hozzászólás, összesen 12 alkalommal lett korlátozva. Két, a vita 9. napján elhangzó felszólalást - melyeket Klebelsberg Kunó és Maday Gyula (\#159, \#227) adtak elő - leszámítva valamenynyi korlátozás ellenző hozzászólást érintett. A\#159-es hozzászólás alatti ülésvezetői közbevetés csupán hangosabb beszédre kérte a minisztert, így ez nem is tekinthető érdemi limitálásnak (az alábbi számításokban ezért nem jelenik meg). Kéthly Annát (\#7) - az idő lejártára hivatkozva - két alkalommal figyelmeztette Zsitvay Tibor, míg Zsirkay János (\#43) hozzászólása esetében szintén az elnök tagadta meg a képviselö hosszabb hozzászólás iránti igényét, egy ízben pedig az idő lejártára figyelmeztette. Drozdy Győző hozzászólását (\#52), visszamenőlegesen, tartalmi szempontból kritizálta az elnök, utalva annak sértő jellegére. A szintén Drozdy által elmondott \#55-ös hozzászólást kétszer, imparlamentáris kifejezések alkalmazására utalva korlátozta az elnök. Kiss Menyhért (\#87) időbeli korlátozását időrendben Lendvai István (\#94) kétszeri figyelmeztetése követte, ezek tárgyát egy ülésvezető korábbi tevékenysége jelentette.

A korlátozott hozzászólások számát az egyes szakaszokban (illetve a teljes érdemi vitában) elhangzott hozzászólások számával egybevetve a 6. táblázatot kapjuk.

6. táblázat. A hozzászólások korlátozásának attitüd szerinti megoszlása a vita egyes szakaszaiban

\begin{tabular}{|l|c|c|c|}
\hline & Általános vita I/N & Részletes vita I/N & Teljes vita I/N \\
\hline Támogató & $0 / 13$ & $1 / 11$ & $1 / 24$ \\
\hline Ellenző & $6 / 12$ & $0 / 18$ & $6 / 30$ \\
\hline
\end{tabular}

Hasonlóan a gráfok elemzéséhez, itt is $3 \mathrm{db} 2 * 2$-es kereszttáblára bontható a táblázat. $\mathrm{Az}$ alacsony elemszám miatt itt már minden esetben a Fisher-féle egzakt próbát alkalmaztam. Míg az általános vita ( $1 / \mathrm{a})$ esetében a $\mathrm{P}=0,03$, így a nullhipotézis elvehető, addig a részletes vita $(1 / b)$ és a teljes érdemi vita (1) értékei $\left(P_{\text {részletes }}=0,40 ; P_{\text {teljes }}=0,22\right)$ nem teszik lehetővé ezt, ezekben az esetekben a próba nem mutatott ki szignifikáns összefüggést.
A második hipotézist, miszerint

a javaslatot támogató és ellenzó hozzászólások eltérố mértékben

\section{hivatkozzák a korábban}

elhangzó pozitív és negatív attitúdú hozzászólásokat (2), nem

tudtam igazolni. Az elemzés során csupán a támogatók felé irányuló hivatkozások többségét (a teljes mintázat közel kétharmada) sikerült kimutatni, de úgy tünik, ez a preferencia a hozzászólás attitúdjétól független. Különbségek mutatkoztak azonban abban a kérdésben, hogy az egyes hozzászólások mennyire hajlamosak velük azonos vagy ellentétes attitúdú megnyilvánulások referálására. Mig a támogatók esetében az ellenzók mellózése volt jellemzó (fóképp a létszámbéli arányok figyelembe vételével), addig az ellenzó attitúdúek inkább hajlamosak az eltéró álláspontok felelevenitésére. 


\section{Összegzés}

Az általános vita folyamán átlagosan minden harmadik megnyilvánulás esetén tapasztalható volt valamilyen korlátozás az ülésvezető részéről, míg a támogatók esetében erre egyetlen alkalommal sem került sor. A részletes vitában - annak ellenére, hogy közel ugyanannyi hozzászólásra kerül sor - ezek a típusú korlátozások visszaesnek. Ezzel összefüggésben a hipotézisek első csoportját, miszerint a törvényjavaslat vitája során az elnöklő személy eltérő mértékben korlátozza a javaslatot ellenzők hozzászólásainak terjedelmét és tartalmát, mint a támogató hozzászólásokét, részlegesen tudtam bizonyítani. Míg az általános vita (1/a) során összefüggés mutatkozik az attitüd és a korlátozottság között, addig ez a részletes vitában $(1 / \mathrm{b})$ nem mutatható ki, az állítás pedig nem terjeszthető ki a teljes vitára sem (1). Az értelmezést jelentősen befolyásolja, hogy az időben korlátozott ellenzéki képviselők minden alkalommal a vitatéma utolsó hozzászólói voltak (ez a 1. és 2. ábráról is könnyen leolvasható), így a tanácskozásra szánt idő lejárta miatt a házszabálynak megfelelően figyelmeztette őket az elnök. Bár tartalmi vonatkozásban a hozzászólások általános vita alatti korlátozásának aránya - 0 támogató és 3 ellenző - sejtések megfogalmazására elegendő, az alacsony elemszámból eredően nem bizonyítható az összefüggés.

A második hipotézist, miszerint a javaslatot támogató és ellenző hozzászólások eltérő mértékben hivatkozzák a korábban elhangzó pozitív és negatív attitüdü hozzászólásokat (2), nem tudtam igazolni. Az elemzés során csupán a támogatók felé irányuló hivatkozások többségét (a teljes mintázat közel kétharmada) sikerült kimutatni, de úgy tünik, ez a preferencia a hozzászólás attitüdjétől független. Különbségek mutatkoztak azonban abban a kérdésben, hogy az egyes hozzászólások mennyire hajlamosak velük azonos vagy ellentétes attitüdủ megnyilvánulások referálására. Míg a támogatók esetében az ellenzők mellőzése volt jellemző (föképp a létszámbéli arányok figyelembe vételével), addig az ellenző attitüdüek inkább hajlamosak az eltérő álláspontok felelevenítésére.

A hipotézisek harmadik csoportját, vagyis hogy az ellenzők és a támogatók körében eltérö arányban lelhetőek fel források (3/a), nyelők $(3 / b)$ valamint alulról és felülről is izolált csúcsok (3/c), egyik esetben sem tudtam igazolni.

A vita érdekes jelensége, hogy mind a befok, mind a kifok szerint súlyozott hálózat kulcsszereplője Klebelsberg Kunó volt. Miniszteri expozéja (\#4), valamint az általános vita végső fázisában elmondott hozzászólása (\#108) markáns keretet adott a nemzetgyülési vitának. Előbbi felszólalásának pozíciója kevésbé meglepő, hiszen egy törvényjavaslat vitájában értelemszerüen meghatározó a miniszteri előterjesztés. A kifok szerint súlyozott hálózatban való elsőség részben magyarázható a kronológiai előnnyel, de a mintegy 10 tényleges és 18 ,,?”-es hivatkozás (valamint ezek diverzitása) azt igazolja, hogy Klebelsberg komoly energiát szánt az addig elhangzott felszólalások áttekintésére és összefoglalására is.

Áttekintve a hipotéziseket és a kiegészítő vizsgálatokat, megállapítható, hogy a korábban közölt kutatási részeredmények csak korlátozott mértékben terjeszthetőek ki a teljes vitára. Ennek egy része abból adódik, hogy a vita feldolgozásának előrehaladtával a vizsgálat módszertana, az egyes hozzászólások és hivatkozásaik, valamint megannyi járulékos elem (jelenség) besorolása is finomodott - ezeket ebben a tanulmányban természetesen egységesen, a vita első felére kiterjesztve is alkalmaztam. A másik faktort a vita strukturális jellemzői, pontosabban a diskurzus második felének az elsőtől sok szempontból elütő jellege adta. Ezen a ponton a nem tényleges hivatkozások aránya mindenképpen megemlítendő. Ezek jelentős száma arra utal, hogy az egyes hozzászólások 
többségében nem a korábbi megnyilvánulásokra reflektáltak, hanem egyes személyekre, korábbi javaslatokra, vagy - a naplót elemző személy által - egyértelmúen nem azonosítható hozzászólásokra (illetve azok csoportjaira). Utóbbi halmaz olyan méretüre duzzad, hogy - ha csak virtuális csoportként is, de - a miniszteri elöterjesztést is felülmúló hivatkozottságot ér el.

Zárásként szeretném megemlíteni, hogy az elvégzett vizsgálatok nem kezelik kielégítő mértékben a felszólások eltérő időpontjaiból származó előnyöket és hátrányokat. Ezért a vita kronológiai sajátosságait érdemben figyelembe vevő modell felállítást a kutatás egyik jövőbeni feladatának tekintem. Jelentős adalékokat szolgáltatna továbbá annak vizsgálata, hogy ez a hivatkozási mintázat mennyiben harmonizál a vita hozzászólásainak mondanivalójával, és hogy a 3. hipotézis kapcsán kimutatott preferencia kiterjeszthetö-e a felszólalások tartalmára is.

\section{Irodalomjegyzék}

Baján Gyula (1922, szerk.): Parlamenti almanach az 1922-1927. évi Nemzetgyülésre. MTI, Budapest.

Boros Zsuzsanna és Szabó Dániel (2008): Parlamentarizmus Magyarországon (1867-1944). ELTE Eötvös Kiadó, Budapest.

Drabancz M. Róbert (2000): Egy európai magyar kultúrpolitikus. Pedagógiai Szemle, 50. 7-8. sz. 195-199.

Klebelsberg Kuno (1927): Beszédei, cikkei és törvényjavaslatai 1916-1925. Athenaeum, Budapest.

Kulcsár Kálmán (1996): Jogalkotás és jogrendszer. In: Kollega Tarsoly István (szerk.): Magyarország a XX. században. I. Babits, Szekszárd. 441-490. 2014. 02. 01-i megtekintés, http://mek.niif.hu/02100/02185/ $\mathrm{html} / 91 . \mathrm{html}$

Nagy Péter Tibor (2000): A húszas évek középiskolapolitikájának kialakulása. Századok, 134. 6. sz. 1313-1334.

NN (1922) = Nemzetgyülési Napló, 1922. XXII. kötet

Sanda István Dániel (2008): Számítógépes diskurzusés tartalomelemzés - Új lehetőségek a pedagógiatörténeti kutatások területén. In: Pukánszky Béla (szerk.): A neveléstörténet-írás új útjai. Gondolat, Budapest.
Simon Gyula (1959): Az 1924-es középiskolai reform néhány kérdése. Pedagógiai Szemle, 9. 6. sz. $543-$ 553.

Szabó Attila (2000): Az 1924. évi középiskolai reform. Új Pedagógiai Szemle, 50. 7-8. sz. 200-204.

Szabó Zoltán András (2013): Az 1924. évi középiskolai törvény parlamenti vitájának diskurzuselemzése kutatási részeredmények. In: Baska Gabriella, Hegedüs Judit és Nóbik Attila (szerk.): A neveléstörténet változó arcai. ELTE Eötvös Kiadó, Budapest. 52-68.

T. Kiss Tamás (1998): Állami müvelödéspolitika az 1920-as években. Magyar Müvelődési Intézet - Mikszáth Kiadó, Budapest.

Varga Kornél (2008): Egy új számítógépes diskurzuselemző technológia. In: Pukánszky Béla (szerk.): A neveléstörténet-irás új útjai. Gondolat, Budapest.

Varsányi Erika (2013): A szociáldemokraták rendszerkritikája az ún. Bethlen-Peyer-paktum megkötése után. In: Feitl István, Sipos Balázs és Varga Zsuzsanna (szerk.): Rendszerváltások kortársa és kutatója: Tanulmánykötet Izsák Lajos 70. születésnapjára. ELTE Eötvös Kiadó, Budapest. 105-110. 


\section{Jegyzetek}

${ }^{1}$ E tanulmány az ELTE Neveléstudományi Doktori Iskolájában készülő disszertációmhoz (cím: A trifurkáló fiúközépiskola-rendszer megszületése Magyarországon 1921-1924) kapcsolódik. Jelen írás emellett a 2013-ban Szegeden megrendezett $A$ múlt értékei, a jelen kihívásai és a jövő? címet viselö nemzetközi workshop, valamint az ott elhangzott elöadásom szerkesztett, magyar nyelvű változatát közreadó tanulmány (Szabó Z. A., 2013) folytatásaként készült. A korábbi közlemény a vizsgálat tárgyát képező parlamenti vita ötödik napjáig - azaz első feléig bezárólag elemezte a kérdést. Ezeket a kutatási részeredményeket jelen tanulmány a vita második felének elemzésével, új problémafelvetésekkel, korrigált besorolási szisztémával és módszertannal egészíti ki. Az ismétlést elkerülendő nem lettek feltüntetve, de a korábbi tanulmány elméleti-módszertani háttere és az előzmények megállapításai szintén felhasználásra kerültek ebben az írásban. Ebből adódóan egyes pontokon elöfordulhat szövegszerü egyezőség.

${ }^{2}$ Ezt a hiányt jelen írás is csak részlegesen kívánja pótolni.

${ }^{3}$ Minisztersége későbbi éveiben más témák kapcsán is használja a jelzőt.

${ }^{4}$ A zárójeles elnevezések gráfelméleti analógia mentén születtek - ld. bővebben a Módszerek címü fejezetben.

${ }^{5}$ A tanulmánynak - bár módszertanában jelentősen támaszkodik a hálózatelméletre - nem célja bemutatni a pedagógia és a hálózatelmélet metszetének metodológiai hátterét, egyéb lehetséges kapcsolódási pontjait, csupán annyit, amennyi a konkrét kutatási probléma bemutatásához feltétlenül szükséges.
${ }^{6}$ Körmentes az a gráf, melynek egyetlen csúcsához sincs ugyanonnan induló és ugyanott végződő irányított út. A kronológiai sorrendből adódó linearitás okán ezek a gráfok csak körmentesek lehetnek (amennyiben egy képviselő saját hozzászólásának egy korábbi szakaszára való reagálását nem számítjuk - ebben az esetben hurokél jönne létre).

${ }^{7}$ A vizsgálat eredményeit nem a felvetett hipotézisek sorrendjében mutatom be, így kapcsolódó feltételezések sorszámát minden esetben feltüntettem.

${ }^{8}$ Ennek ellenére a vita egyes napjaira való hivatkozások esetében - az egyértelműség kedvéért - kifejezéstől függetlenül mindig az abszolút (1-10. nap) számozást követem.

${ }^{9}$ Ezért is pontosabb lenne a 'megnyilvánulás' kifejezés következetes alkalmazása, de a szóismétlést elkerülendő ezt ekvivalens fogalomként használom a 'hozzászólás'-sal.

${ }^{10}$ Hozzá kell tenni, hogy az ezen a napon elhangzó határozati javaslatok szövegét nem tünteti fel a napló, így ez némileg torzítja az eredményeket.

${ }^{11}$ A színezés és a címkék ugyanazon elvek alapján készültek, mint az előző gráf esetében.

12 \#14; \#40; \#49; \#55; \#68; \#76; \#87; \#91; \#97; \#103; \#106; \#143; \#149; \#151; \#159; \#169; \#177; \#182; \#184; \#190; \#201; \#203; \#208; \#217; \#222; \#231

${ }^{13}$ \#?; \#2; \#65; \#174; \#188; \#195; \#197

14 \#110; \#147; \#224 